Or.

(C) The authors. Published by Universidad Nacional Agraria La Molina

\title{
Germination behavior of Jatropha curcas L. after different imbibition times
}

\author{
Comportamiento de germinación de Jatropha curcas L. después de diferentes tiempos de imbibición
}

\author{
Lozano, F. ${ }^{1}$; Miranda,P. ${ }^{1}$; Pompelli, M. ${ }^{1 *}$ \\ *Corresponding author: marcelo.pompelli@ufpe.br
}

\begin{abstract}
Jatropha curcas is an important specie for production of biofuel. The specie can survive and produce fruits and seeds even in drought condition. For an adequate establishment in the field is necessary that seeds have a good quality in vigor and viability. In this study, we evaluated the seed water relation with different imbibition times, in deionized water, from 0 to 24 hours. Imbibed seeds were sown in polyethylene trays with 1,200 g of river sand. The germination was recorded every day for 25 days. Seeds with at least $10 \mathrm{~mm}$ radicle on the soil surface was considered as germinated. To determinate seed water content (SWC), 10 seeds were weighed in fresh (SFW), turgid (STW) and dry weight (SDW) at $105^{\circ} \mathrm{C}$ for 24 hours. After 24 hours of imbibition our results show a decrease in the germination rate from $85 \%$ to $47 \%$, and an increase of the mean germination time from 4.8 to 7.1 days. The initial moisture of the seed used in this experiment was about $8 \%$ and after 24 hours of imbibition, the SWC was around $60 \%$. The initial low moisture in the seeds produce imbibition damage because the tissue hydration takes place in a not controlled way so that the reconstruction of internal structures of the cells and organelles were affected. According to the PCA analysis the seed germination had a negative correlation with the imbibition time $(r=-0.72, p<0.05)$ and with the electrical conductive $(r=-0.88, p<0.05)$, variables related to the seed vigor. This study suggests that electrical conductivity may be useful in $J$. curcas for vigor test and their seeds do not need previously water imbibition to improve germination from seeds with initial moisture less than $8 \%$.
\end{abstract}

Key words: Biofuel, seed water content, seed moisture, germinability

\section{Resumen}

Jatropha curcas es una especie importante para la producción de biocombustible. La especie puede sobrevivir y producir frutos y semillas incluso en condiciones de sequía. Para un establecimiento adecuado en el campo es necesario que las semillas tengan una buena calidad en vigor y viabilidad. En este estudio, evaluamos la relación agua de la semilla con diferentes tiempos de imbibición, en agua desionizada, de 0 a 24 horas. Las semillas embebidas se sembraron en bandejas de polietileno con 1,200 g de arena de río. La germinación se registró todos los días durante 25 días. Las semillas con al menos $10 \mathrm{~mm}$ de radícula en la superficie del suelo se consideraron germinadas. Para determinar el contenido de agua de la semilla (SWC), se pesaron 10 semillas en fresco (SFW), turgentes (STW) y peso seco (SDW) a $105^{\circ} \mathrm{C}$ durante 24 horas. Después de 24 horas de imbibición, nuestros resultados muestran una disminución en la tasa de germinación de $85 \%$ a $47 \%$, y un aumento del tiempo de germinación promedio de 4.8 a 7.1 días. La humedad inicial de la semilla utilizada en este experimento fue de aproximadamente $8 \%$ y después de 24 horas de imbibición, el SWC fue de alrededor del $60 \%$. La baja humedad inicial en las semillas produce daño por imbibición debido a que la hidratación del tejido tiene lugar de una manera no controlada, de modo que la reconstrucción de las estructuras internas de las células y los orgánulos se vieron afectadas. De acuerdo con el análisis de PCA, la germinación de la semilla tuvo una correlación negativa con el tiempo de imbibición $(r=-0.72, p<0.05)$ y con la conductiva eléctrica $(r=-0.88, p<0.05)$, variables relacionadas con el vigor de la semilla. Este estudio sugiere que la conductividad eléctrica puede ser útil en $J$. curcas para la prueba de vigor y sus semillas no necesitan previamente imbibición de agua para mejorar la germinación de las semillas con una humedad inicial inferior al $8 \%$.

Palabras clave: Biocombustible, contenido de agua de la semilla, humedad de la semilla, germinabilidad

\section{Introduction}

Jatropha curcas L. belongs to the family Euphorbiaceae, is native from the American tropics (Abhilash et al., 2010). This species looks like a small tree with $6 \mathrm{~m}$ in height (Sunil et al., 2013). J. curcas is a seed-bearing plant and can produce from 1,500 to $2,000 \mathrm{~kg}$ of seed per hectare/ year or 540 to 680 liters of biofuel per hectare, considering that $J$. curcas seeds contain about $40 \%$ to $58 \%$ of oil (Pandey et al., 2012; Marcelo Francisco Pompelli et al., 2010). Moreover, J. curcas is a non-edible, eco-friendly, non-toxic, biodegradable fuel-producing plant that has attracted worldwide attention as an alternative sustainable 
energy source for the future (Dharma et al., 2017). This species can be cultivated on marginal and salt affected areas, without competing with crop food production (Elhag and Gafar, 2014). In general, more than 95\% of the oil produced for biodiesel purposes comes from edible oils, like corn and soy, which can have a negative impact on food production (Khan et al., 2014). Thus, J. curcas seeds seems as a good source of oil and it has great economic potential as an alternative biofuel (Berchmans and Hirata, 2008; Chen et al., 2008).

The seeds of $J$. curcas have a short viability period and they are more sensitive to salinity at germination (Elhag and Gafar, 2014; Moncaleano-Escandon et al., 2013). J. curcas is drought tolerant (Arcoverde et al., 2011; Marcelo F. Pompelli et al., 2010) and probably also has salinity tolerant (Lozano-Isla, in press).

Seed deterioration is a natural and irreversible process, even under ideal storage conditions (Castellión et al., 2010; Copeland and McDonald, 1999; Marcos-Filho, 1998; Moncaleano-Escandon et al., 2013). While deterioration is both irreversible and inevitable, the speed of the process can be controlled with appropriate harvesting, drying and storage techniques. There are several factors that are known to influence the progress of deterioration during seed storage. Both high temperatures and humidity during storage increase the deterioration speed of seeds (Copeland and McDonald, 1999; Pukacka et al., 2009), and decreasing either of these factors significantly increases the storage life of seeds (Castellión et al., 2010). Dry seeds suffer a variety of biochemical and metabolic changes, including lipid peroxidation, enzyme inactivation and rupture of cellular membranes (Alencar et al., 2015; MoncaleanoEscandon et al., 2013).

In another way, seed imbibition is an important process in the plant life cycle and determines whether seed germination and plant growth will be successful or not (Ribeiro et al., 2015). In arid environments, the water needed for germination is available for only short periods and consequently, successful crop establishment depends not only on rapid and uniform germination of the seed, but also on the ability of the seed to germinate under low water availability (Windauer et al., 2007). The speed and uniformity of seed germination are prominent parameters especially for field crop seeds to compete with weed seeds (Ruttanaruangboworn et al., 2017). Water uptake is the fundamental requirement for the initiation and completion of seed germination (Koornneef et al., 2002). Studies on germination and seedling establishment, which are the critical stages in the plant life cycle and in J. curcas, have not been conducted. Knowledge of the capacity of the species to complete this stage successfully is fundamental for crop production (Windauer et al., 2011). Considerable variation was registered in J. curcas for seed germination, seedling growth and biomass parameters. The small value of error or environmental variances of the seedling growth traits suggest that the majority of characters are under genetic control (Ginwal et al., 2005).
Based on these, the main objective of this study was to evaluate the behavior of $J$. curcas seeds under different imbibition time, seed water relation and aspects about germination.

\section{Materials and Methods}

Plant material-The experiment was carried out with $2 \mathrm{~kg}$ of Jatropha curcas seeds its where collected in a commercial plantation from the Atlantic rain forest region (09 $28^{\prime} \mathrm{S}$; 35 $35^{\circ}$ 'W m.a.s.1.). The plantation consisted of plants that were at least 8 years of age, and the spacing between plants was $2 \mathrm{~m} \times 2 \mathrm{~m}$. Fruits of $J$. curcas were randomly collected during the rainy season from 2015 . The seeds presented $72 \%$ viability and stored as recommended by Moncaleano-Escandon et al. (2013).

Seed imbibiton test and water relation-The seeds were distributed in 52 frasks $(400 \mathrm{~mL})$ with 25 seed for each replication treatment in a controlled room chamber at $25^{\circ} \mathrm{C}$. For each frask, $100 \mathrm{ml}$ deionized water was applied and the seeds were soaked according to the imbibition treatments $(0,2,4,6,8,10,12,14,16,18,20,22$ and 24 hours $)$. The $\mathrm{pH}$ (W3B, Bel Engineering, Italy) and electrical conductivity (CD-4306, Lutron, Taiwan) were evaluated with $20 \mathrm{~mL}$ of soaking solution for each imbibition treatment. For seed water content, $50 \mathrm{~mL}$ deionized water was applied in frasks of $100 \mathrm{~mL}$ and were added 10 seed previously weighted in an analytic scale, according to different imbibition time. After each treatment was take the seeds imbibition weight and putted in papers bags for oven at $105^{\circ} \mathrm{C}$ for 24 hours and determinate seeds dry weight. The water relation variables were calculated according the following formulas: $\operatorname{SMT}(\%)=1-(S d w / S f w) * 100$ and $S W C(\%)=(S t w-$ $S f w) / S f w^{*} 100$. Where $S M T(\%)$, Seed moisture; $S W C(\%)$ Seed Water content; $S d w(g)$, Seed dry weight; $S f w(g)$, Seed fresh weight and $\operatorname{Stw}(g)$, Seed turgid weight.

Germination test-For each replication treatment, 25 seeds were uniformly distributed in polyethylene trays content $1000 \mathrm{~g}$ of river sand and covered with $200 \mathrm{~g}$ of the substrate. The germination experiment was carried out in greenhouse condition with average temperature of $27.5^{\circ} \mathrm{C}$ and $78 \%$ relative humidity. Seed germination was evaluated daily according to agronomic criteria consider germinated seed when the radicle had emerged about $10 \mathrm{~mm}$ above the soil surface. When no additional germination was observed in all treatments at least in five consecutive days, the germination was considered completed (MoncaleanoEscandon et al., 2013).

Data analysis - The experiment was carried out in a completely randomized design with 13 treatments of imbibition times $(0,2,4,6,8,10,12,14,16,18,20$, 22 and 24 hours) with four replications with seeds of $\mathrm{J}$. curcas. Statistical analysis were performed in the statistical software R (R Core Team, 2017). The analysis of variance 
(ANOVA) was performed to evaluate the differences between the factors and the comparison of the means with the Student-Newman-Keuls test $(\mathrm{p}<0.05)$ (de Mendiburu, 2017). The germination variables and graphs were performed according the GerminaR R package (Lozano Isla et al., 2017). For the multivariate analysis, correlation analysis (de Mendiburu, 2017; Wei and Simko, 2017) and principal component analysis were conducted (Husson et al., 2017).

\section{Results}

Electrical conductivity and pH evaluation-The water solution from the soaked seeds showed variation under the imbibition time for electrical conductivity (EC) and $\mathrm{pH}$, Figure $1 \mathrm{~A}-\mathrm{B}$. The $\mathrm{pH}$ range from 7.7 to 5.1 showing difference between the different imbibition time with a reduction of the $\mathrm{pH}$ in the time $(\mathrm{r}=-0.88, \mathrm{p}<0.05)$, Figure 1 A. While the EC show an increase in relation to imbibition time $(\mathrm{r}=0.80, \mathrm{p}<0.05)$ with value ranges from 0.021 to $0.69 \mathrm{dS} \mathrm{m}^{-1}$, Figure $1 \mathrm{~B}$. According the correlation analysis exits a negative correlation between $\mathrm{EC}$ and $\mathrm{pH}(\mathrm{r}=-0.74$, $\mathrm{p}<0.05)$.

Seed water relation - The initial seed moisture (SMT) was $7.9 \%$ and after 24 hours of imbibition was $9.5 \%$, Figure 1 C. The SMT show a strong positive correlation with the imbibition time $(r=0.89, p<0.05)$. While the seed water content (SWC) show a fast increase reaching up to $25.7 \%$ until the first two hour of imbibition; afterwards, the SWC increases continuously to about $59.2 \%$ in 24 hours shown an increase around 6.5 times from initial values. Figure 1 $\mathrm{D}$; this results is supported for a high correlation between imbibition time with the SWC $(r=0.93, p<0.05)$. Also exist a high correlation $(r=0.96, p<0.05)$ between SMT and SWC.

Seed germination analysis-Initial germinability of $85 \%$ of the seeds of $J$. curcas decreases significantly after 2 hours of imbibition. After that, the range of germinability was $68 \%$ to $44 \%$ from 2 to 24 hour of imbibition (Figure 2 A), showing a strong negative correlation with imbibition time $(r=-0.72, p<0.05)$. The mean germination time from seed without imbibition has a value at 4.8 day in comparison with the other treatments with values around 5.9 to 7.1 day for germination for 2 to 24 hours of imbibition (Figure 2 B). Seed germinability presented a negative strong correlation with a mean germination time $(\mathrm{r}=-0.88, \mathrm{p}<0.05)$. The germination synchrony did not show difference between the imbibition times (Figure $2 \mathrm{C}$ ). For the experiment, the maximum value for the uncertainty is 4.64 bits and the values ranged from 1.86 to 2.34 bits without difference between treatments and the results didn't show any trend with the imbibition time. While the germination synchrony show a high correlation $(\mathrm{r}=-0.92$, $\mathrm{p}<0.05)$ with the germination uncertainty.
Multivariate analysis - The principal component analysis according to the studied variables explain $75.03 \%$ of the variance between the first and second dimension. In the first dimension there is a high positive correlation between ELC $(r=0.97, p<0.05)$, SWC $(r=0.96, p<0.05)$, SMT $(\mathrm{r}=0.91, \mathrm{p}<0.05)$, STW $(\mathrm{r}=0.91, \mathrm{p}<0.05)$, IBTH $(\mathrm{r}=$ $0.87, \mathrm{p}<0.05)$, MGT $(\mathrm{r}=0.82, \mathrm{p}<0.05)$ with a negative correlation with the GRP $(\mathrm{r}=-0.92, \mathrm{p}<0.05)$. While in the second dimension SFW $(r=0.77, \mathrm{p}<0.05)$, SDW $(r=0.71$, $\mathrm{p}<0.05)$ present positive correlation in contrast with HPT $(r=-0.75, p<0.05)$ with negative correlation (Figure 3$)$.

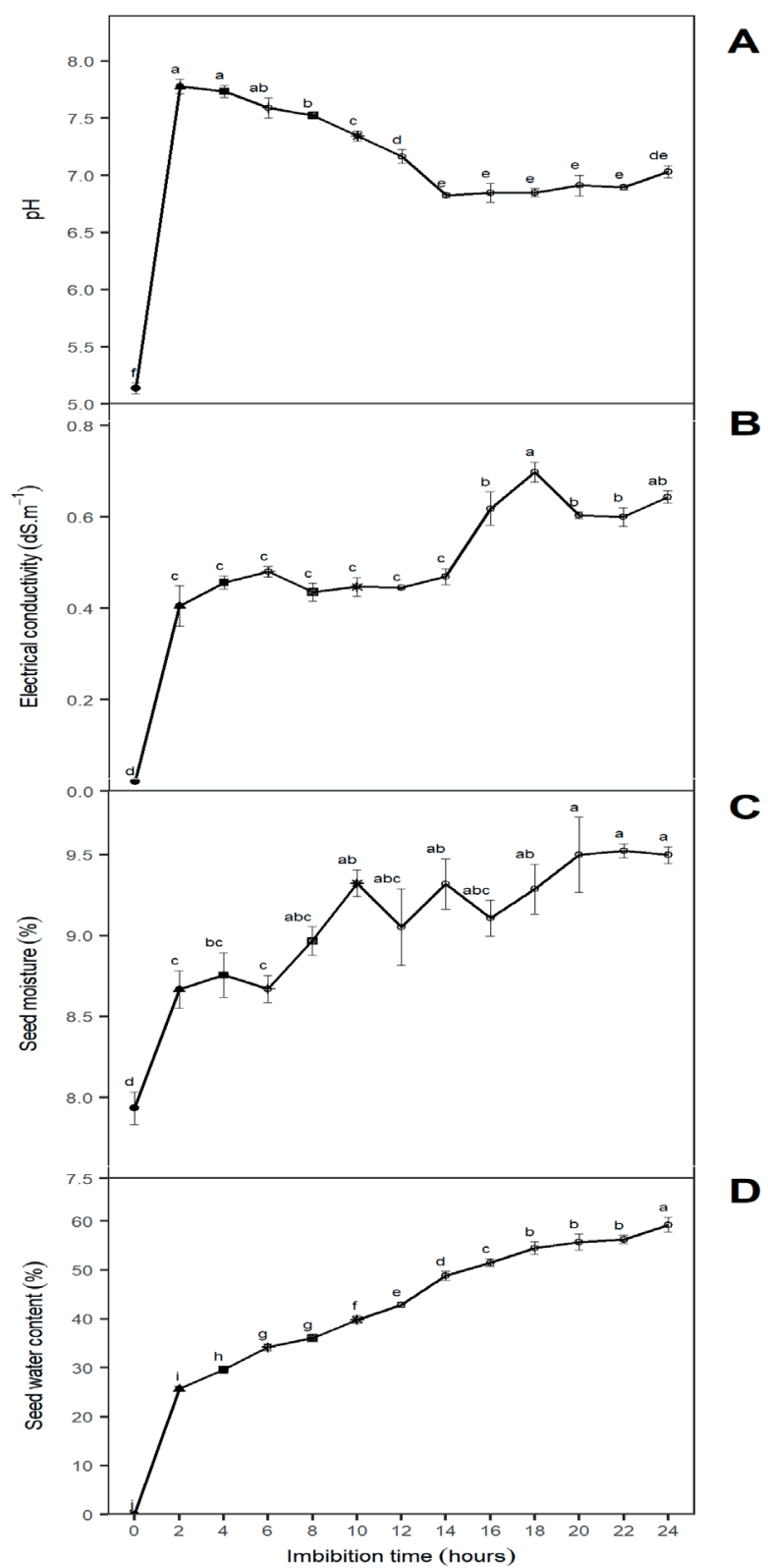

Figura 1. Response of Jatropha curcas seeds after different imbibition time. (A) $\mathrm{pH}$; (B) Electrical conductivity; (C) Seed moisture and (D) Seed water content. The letter represent the mean difference with Student-NewmanKeuls test $(p=0.05)$. Means are represent with $( \pm S E) . n$ $=4$. 


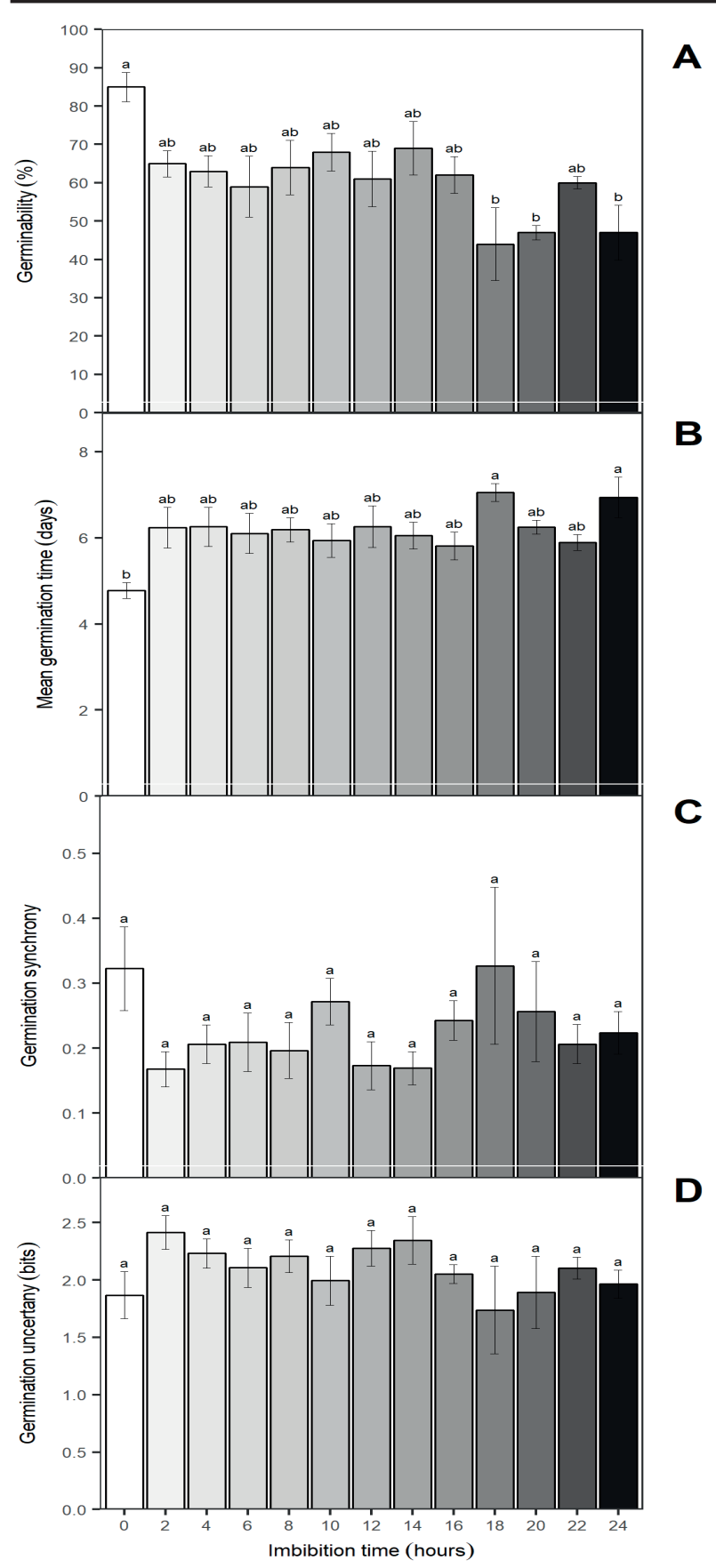

Figure 2 Germination response in Jatropha curcas seeds after different imbibition times. (A) Germination (\%); (B) Mean germination time (days); (C) Germination synchrony and (D) Germination uncertainty (bits). The letter represent the mean difference with Student-Newman-Keuls test $(\mathrm{p}=$ $0.05)$. Means are represent with $( \pm S E) . n=4$.

\section{Discussion}

The water content in seeds with impermeable seed coats has important implications for germination, because impermeable coats prevent germination until environmental conditions promote water absorption by seeds followed by germination (Kestring et al., 2009; Ribeiro et al., 2015). This study found a reduction in the seed germination of $J$. curcas, according to seed water

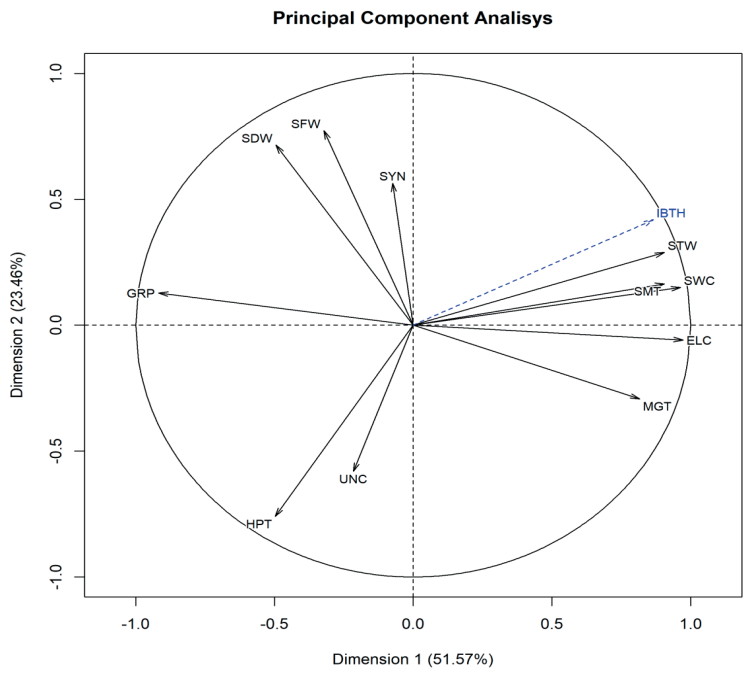

Figure 3. Principal Component Analysis from the variables in Jatropha curcas seeds after different imbibition times. Where: IBTH, imbibition time; GRP, germination percentage; MGT, mean germination time; SYN, germination synchrony; UNC, germination uncertainty; $\mathrm{pH}$, potential of hydrogen; EC, electrical conductivity; SWC, seed water content; SMT, seed moisture; SDW, seed dry weight; SFW, seed fresh weight; STW, seed turgid weight.

imbibition. It is supposed that seeds need a small amount of water for promote the germination because the water imbibition had linearly decrease the germinability and increase its mean germination time, two parameters related to the seed vigor. This phenomena was previously reported in other species, like corn (Matthews and Hosseini, 2006), rice (Ruttanaruangboworn et al., 2017) castor oil (Ribeiro et al., 2015) and Astrophytum species (Sánchez-Salas et al., 2012); however, in contrast of Mimosa bimucronata (Kestring et al., 2009) a floodplain species, where the water uptake sharply increases the seed germination. Also, it was observed during the time line of the experiment there was an increase in EC that reflect in lost the seed germinability from seed steeping in water from 2 to 24 hours.

The seeds used in this experiment were stored in dry environments and hence had very low levels of metabolism. We argue that, during seed imbibition, they swell and metabolic activity increases. Hydration of tissue components during imbibition takes place in a not controlled way so that the reconstruction of internal structures of the cells and organelles were affected. Therefore, leakage of stored components and enzymes, coloring, cracking or absence of cotyledons, and overall damage to the hypocotyl may occur during germination (Hobbs and Obendorf, 1972; Pollock et al., 1969). The amount of the constituents of the leaked depended unequivocally on the initial water content of seeds; the lower moisture in seed at the initial water content show more leakage occurring in seeds with low water contents, below $10 \%$ in soybeans seeds (Ishida et al., 1988). This damage takes place in the early stages of 
imbibition (Parrish and Leopold, 1977). This indicates that membrane functions are restored, even though the activities of respiration and metabolism are restricted. Water molecules are semi-bound and mobile water necessary for metabolism is deficient for moisture contents between $12-24 \%$ (Koizumi et al., 2008). According to these, the loss of viability can be explained base on the initial seed water content of the seeds used in the experiment because they had an initial moisture around $8 \%$, that is low value compared with the moisture at harvest that is around $18 \%$ (Marcelo Francisco Pompelli et al., 2010).

A possible explanation could be the loss of water by storage condition of the seed for the experiment. In other crops like soybean seeds, water content is usually 10 to $20 \%$ at harvest and falls further during storage, seed water contents below $10 \%$ were shown to be desirable for long period storage because seeds stop their biological activities and the stored materials are consumed at a minimum level (Windauer et al., 2007). J. curcas seeds after 24 hour of imbibition increases 6.5 times its initial moisture as reported in soybean seeds (Ishida et al., 1988). Dried seeds can raise their water content to a certain level, two or three times the dry weight, and this rapid increase of water is often accompanied by some deterioration of the tissues, called imbibitional damage. This damage is expressed as a reduced rate of germination and reduced yield of surviving plants (Ishida et al., 1988). It can be the reason in decrease in the germination percentage in this research. It was reported that soybean seeds with the water content below $13 \%$ suffered seriously from imbibitional damage while those above $17 \%$ did not, where respiration and metabolic activity rapidly increase with the increase of moisture content (Ishida et al., 1988; Vertucci and Leopold, 1984).

Imbibition damage results from the rapid entry of water into the cotyledons during imbibition, leading to cell death and high solute leakage from the seeds (Powell et al., 1986) and the extensive loss of cellular material and enzymes from the seeds (Duke and Kakefuda, 1981; Powell and Matthews, 1981) indicates extensive membrane disruption. The electrical conductivity was related to seed water content and the germination for this reason EC tests has been applied to detect vigor differences in many other grain legumes and indeed some other species (Hampton and Tekrony, 1995; Moncaleano-Escandon et al., 2013). The conductivity will increase as the laboratory germination falls, in addition to the reduced ability of germination seeds to retain cell contents (Matthews and Hosseini, 2006). Reports on pea lots, the EC readings for lots have been found to relate significantly to field emergence (Powell and Matthews, 1981; Thornton et al., 1990).

To alleviate the effects of imbibition damage as a result of the increase in the water content of seeds, a slow and controlled hydration is essential as the first step in the reactivation of metabolic processes in dry seed (Vertucci and Leopold, 1984) leading an increase in the germination and growth ability. The EC vigor test would be developed and standardized for these species (Abdullah et al., 1991;
Powell, 1986; Yaklich and Kulik, 1979). Furthermore, it was reported than the relationship between field emergence and EC turned out to be not only interesting, but useful in practical seed technology (Matthews and Powell, 2006) as present in these work for $J$. curcas.

\section{Conclusions}

The initial water content in $J$. curcas seeds should be consider at germination because it will alter seed germinability according to the imbibition time. The EC measurement could have a role such us ageing based vigor test or controlled deterioration test, by giving a measure of viability in 24 hours in place of a normal germination test that takes around 15 days or longer in J. curcas.

\section{Acknowledgments}

The authors thanks the National Council for Scientific and Technological Development (CNPq Grants 404357/20130 ) for financial support to the work execution. The first author thanks the Coordination of Improvement of Higher Education Personnel (CAPES) for the scholarship. The authors would also like to thanks Miriam Vieira De Albuquerque for her support during the experiment and Noellle B. Vanderlei dos Santos for her kind revisions of this manuscript.

\section{References}

Abdullah, W.D., Powell, A.A. and Matthews, S. (1991). Association of differences in seed vigour in long bean (Vigna sesquipedalis) with testa colour and imbibition damage. The Journal of Agricultural Science, 116(2), 259-264. https://doi.org/10.1017/s0021859600077662

Abhilash, P.C., Srivastava, P., Jamil, S. and Singh, N. (2010). Revisited Jatropha curcas as an oil plant of multiple benefits: Critical research needs and prospects for the future. Environmental Science and Pollution Research, 18(1), 127-131. https://doi.org/10.1007/ s11356-010-0400-5

Alencar, N.L.M., Gadelha, C.G., Gallao, M.I., Dolder, M.A.H., Prisco, J.T. and Gomes-Filho, E. (2015). Ultrastructural and biochemical changes induced by salt stress in Jatropha curcas seeds during germination and seedling development. Functional Plant Biology, 42(9), 865-874. https://doi.org/10.1071/fp15019

Arcoverde, G.B., Rodrigues, B.M., Pompelli, M.F. and Santos, M.G. (2011). Water relations and some aspects of leaf metabolism of Jatropha curcas young plants under two water deficit levels and recovery. Brazilian Journal of Plant Physiology, 23(2), 123-130. https:// doi.org/10.1590/s1677-04202011000200004

Berchmans, H.J. and Hirata, S. (2008). Biodiesel production from crude Jatropha curcas L. seed oil with a high content of free fatty acids. Bioresource Technology, 99(6), 1716-1721. https://doi.org/10.1016/j. 
biortech.2007.03.051

Castellión, M., Matiacevich, S., Buera, P. and Maldonado, S. (2010). Protein deterioration and longevity of quinoa seeds during long-term storage. Food Chemistry, 121(4), 952-958. https://doi.org/10.1016/j. foodchem.2010.01.025

Chen, B., Landsman-Ross, N., Naughton, R. and Olenyik, K. (2008). Jatropha curcas L.: Biodiesel solution or all hype? A scientific, economic and political analysis of the future energy crop. In Energy and Energy policy, Spring 2008 (pp. 1001-1005) Chicago: Chicago University.

Copeland, L.O. and McDonald, M.B. (1999). Seed longevity and deterioration. In Principles of Seed Science and Technology (pp. 181-220). Boston: Springer. https://doi.org/10.1007/978-1-4615-178328

De Mendiburu, F. D. (2015). Agricolae: Statistical procedures for agricultural research, [on line]. Perú. Retrieved from: http://CRAN.R-project.org/ package=agricolae [november, 2017]

Dharma, S., Hassan, M.H., Ong, H.C., Sebayang, A.H., Silitonga, A.S., Kusumo, F. and Milano, J. (2017). Experimental study and prediction of the performance and exhaust emissions of mixed Jatropha curcasCeiba pentandra biodiesel blends in diesel engine using artificial neural networks. Journal of Cleaner Production, 164, 618-633. https://doi.org/10.1016/j. jclepro.2017.06.065

Duke, S.H. and Kakefuda, G. (1981). Role of the testa in preventing cellular rupture during imbibition of legume seeds. Plant Physiology, 67(3), 449-456. https://doi. org/10.1104/pp.67.3.449

Elhag, A.Z. and Gafar, M.O. (2014). Effect of sodium chloride on growth of jatropha (Jatropha curcas L.) young transplants. Universal Journal of Plant Science, 2, 19-22.

Ginwal, H., Phartyal, S., Rawat, P. and Srivastava, R. (2005). Seed source variation in morphology, germination and seedling growth of Jatropha curcas Linn. in central India. Silvae Genetica 54(2), 76-79. DOI: $10.1515 / \mathrm{sg}-2005-0012$

Hampton, J.G. and Tekrony, D.M. (1995). Handbook of vigour test methods. Switzerland: The International Seed Testing Association.

Hobbs, P.R. and Obendorf, R.L. (1972). Interaction of initial seed moisture and imbibitional temperature on germination and productivity of soybean. Crop Science, 12(5), 664-667. https://doi.org/10.2135/crops ci1972.0011183x001200050033x

Husson, F., Josse, J., Le, S. and Mazet, J. (2017). FactoMineR: Multivariate exploratory data analysis and data mining, [on line]. Retrieved from: https://rdrr. io/cran/FactoMineR/ [november, 2017]
Ishida, N., Kano, H., Kobayashi, T. and Yoshida, T. (1988). Analysis of physical states of water in soybean seeds by NMR. Agricultural and Biological Chemistry, 52(11), 2777-2781. https://doi.org/10.1271/bbb1961.52.2777

Kestring, D., Klein, J., Menezes, L.C.C.R. de, and Rossi, M.N. (2009). Imbibition phases and germination response of Mimosa bimucronata (Fabaceae: Mimosoideae) to water submersion. Aquatic Botany, 91(2), 105-109. https://doi.org/10.1016/j. aquabot.2009.03.004

Khan, T.Y., Atabani, A., Badruddin, I.A., Badarudin, A., Khayoon, M. and Triwahyono, S. (2014). Recent scenario and technologies to utilize non-edible oils for biodiesel production. Renewable and Sustainable Energy Reviews, 37, 840-851. https://doi.org/10.1016/j. rser.2014.05.064

Koizumi, M., Kikuchi, K., Isobe, S., Ishida, N., Naito, S. and Kano, H. (2008). Role of seed coat in imbibing soybean seeds observed by micro-magnetic resonance imaging. Annals of Botany 102(3), 343-352. https:// doi.org/10.1093/aob/mcn095

Koornneef, M., Bentsink, L. and Hilhorst, H. (2002). Seed dormancy and germination. Current Opinion in Plant Biology, 5(1), 33-36. https://doi.org/10.1016/s13695266(01)00219-9

Lozano Isla, F., Benites Alfaro, O. and Pompelli, M.F. (2017). GerminaR: Germination indexes for seed germination variables for ecophysiological studies, [on line]. Retrieved from: https://rdrr.io/cran/GerminaR/ [november, 2017]

Marcos-Filho, J. (1998). New approaches to seed vigor testing. Scientia Agricola, 55, 27-33. https://doi. org/10.1590/s0103-90161998000500005

Matthews, S. and Hosseini, M.K. (2006). Mean germination time as an indicator of emergence performance in soil of seed lots of maize (Zea mays). Seed Science and Technology, 34(2), 339-347. https://doi.org/10.15258/ sst.2006.34.2.09

Matthews, S. and Powell, A. (2006). Electrical conductivity vigour test: Physiological basis and use. Seed Testing International 131, 32-35.

Moncaleano-Escandon, J., Silva, B.C., Silva, S.R., Granja, J.A., Alves, M.C.J. and Pompelli, M.F. (2013). Germination responses of Jatropha curcas L. seeds to storage and aging. Industrial Crops and Products, 44, 684-690. https://doi.org/10.1016/j. indcrop.2012.08.035

Pandey, V.C., Singh, K., Singh, J.S., Kumar, A., Singh, B. and Singh, R.P. (2012). Jatropha curcas: A potential biofuel plant for sustainable environmental development. Renewable and Sustainable Energy Reviews, 16(5), 2870-2883. https://doi.org/10.1016/j. rser.2012.02.004

Parrish, D.J. and Leopold, A.C. (1977). Transient changes during soybean imbibition. Plant Physiology 59, 11111115. https://doi.org/10.1104/pp.59.6.1111 
Pollock, B., Roos, E. and Manalo, J. (1969). Vigor of garden bean seeds and seedlings influenced by initial seed moisture, substrate oxygen, and imbibition temperature. Journal of the American Society for Horticultural Science, 94, 577-584.

Pompelli, M.F., Barata-Luís, R., Vitorino, H.S., Gonçalves, E.R., Rolim, E.V., Santos, M.G., Almeida-Cortez, J.S., Ferreira, V.M., Lemos, E.E. and Endres, L. (2010). Photosynthesis, photoprotection and antioxidant activity of purging nut under drought deficit and recovery. Biomass and Bioenergy, 34(8), 1207-1215. https://doi.org/10.1016/j.biombioe.2010.03.011

Pompelli, M.F., Rocha Gomes Ferreira, D.T. da, Silva Cavalcante, P.G. da, Lima Salvador, T. de, Hsie, B.S. de, and Endres, L. (2010). Environmental influence on the physico-chemical and physiological properties of Jatropha curcas seeds. Australian Journal of Botany, 58(6), 421-427. https://doi.org/10.1071/bt10102

Powell, A.A. (1986). Cell membranes and seed leachate conductivity in relation to the quality of seed for sowing. Journal of Seed Technology, 10(2), 81-100.

Powell, A.A., Oliveira, M.D.A. and Matthews, S. (1986). The role of imbibition damage in determining the vigour of white and coloured seed lots of dwarf french beans (Phaseolus vulgaris). Journal of Experimental Botany, 37(5), 716-722. https://doi.org/10.1093/jxb/37.5.716

PowellL, A.A. and Matthews, S. (1981). A physical explanation for solute leakage from dry pea embryos during imbibition. Journal of Experimental Botany 32(5), 1045-1050. https://doi.org/10.1093/ $\mathrm{jxb} / 32.5 .1045$

Pukacka, S., Ratajczak, E. and Kalemba, E. (2009). Nonreducing sugar levels in beech (Fagus sylvatica) seeds as related to withstanding desiccation and storage. Journal of Plant Physiology, 166(13), 1381-1390. https://doi.org/10.1016/j.jplph.2009.02.013

R Core Team (2014). $R$ : A language and environment for statistical computing. $R$ Foundation for Statistical Computing, [on line]. Vienna, Austria. Retrieved from: http://www.r-project.org/ [november, 2017]

Ribeiro, P.R., Willems, L.A., Mudde, E., Fernandez, L.G., Castro, R.D. de, Ligterink, W. and Hilhorst, H.W. (2015). Metabolite profiling of the oilseed crop Ricinus communis during early seed imbibition reveals a specific metabolic signature in response to temperature. Industrial Crops and Products, 67, 305-309. https:// doi.org/10.1016/j.indcrop.2015.01.067

Ruttanaruangboworn, A., Chanprasert, W., Tobunluepop, P. and Onwimol, D. (2017). Effect of seed priming with different concentrations of potassium nitrate on the pattern of seed imbibition and germination of rice (Oryza sativa L.). Journal of Integrative Agriculture 16(3), 605-613. https://doi.org/10.1016/s20953119(16)61441-7

Sánchez-Salas, J., Jurado, E., Flores, J., Estrada-Castillón, E. and Muro-Pérez, G. (2012). Desert species adapted for dispersal and germination during floods: Experimental evidence in two Astrophytum species (Cactaceae). Flora - Morphology, Distribution, Functional Ecology of Plants, 207(10), 707-711. https://doi.org/10.1016/j. flora.2012.08.002

Sunil, N., Kumar, V., Sujatha, M., Rao, G.R. and Varaprasad, K.S. (2013). Minimal descriptors for characterization and evaluation of Jatropha curcas L. germplasm for utilization in crop improvement. Biomass and Bioenergy, 48, 239-249. https://doi. org/10.1016/j.biombioe.2012.11.008

Thornton, J.M., Powell, A.A. and Mattews, S. (1990). Investigation of the relationship between seed leachate conductivity and the germination of Brassica seed. Annals of Applied Biology, 117(1), 129-135. https:// doi.org/10.1111/j.1744-7348.1990.tb04201.x

Vertucci, C.W. and Leopold, A.C. (1984). Bound water in soybean seed and its relation to respiration and imbibitional damage. Plant Physiology, 75, 114-117. https://doi.org/10.1104/pp.75.1.114

Wei, T. and Simko, V. (2017). Corrplot: Visualization of a correlation matrix, [on line]. Retrieved from: https:// github.com/taiyun/corrplot [november, 2017]

Windauer, L., Altuna, A. and Benech-Arnold, R. (2007). Hydrotime analysis of Lesquerella fendleri seed germination responses to priming treatments. Industrial Crops and Products 25(1), 70-74. https:// doi.org/10.1016/j.indcrop.2006.07.004

Windauer, L.B., Martinez, J., Rapoport, D., Wassner, D. and Benech-Arnold, R. (2011). Germination responses to temperature and water potential in Jatropha curcas seeds: A hydrotime model explains the difference between dormancy expression and dormancy induction at different incubation temperatures. Annals of Botany 109(1), 265-273. https://doi.org/10.1093/aob/mcr242

Yaklich, R.W. and Kulik, M.M. (1979). Evaluation of vigor tests in soybean seeds: Relationship of the standard germination test, seedling vigor classification, seedling length, and tetrazolium staining to field performance ${ }^{1}$. Crop Science 19(2), 247-252 https://doi.org/10.2135/cr opsci1979.0011183x001900020019x 